WIELKIE TEMATY KULTURY W LITERATURACH SŁOWIAŃSKICH

Slavica Wratislaviensia CLXVIII • Wrocław 2019•AUWr No 3875

DOI: $10.19195 / 0137-1150.168 .2$

Data przesłania artykułu: 25.09.2017

Data akceptacji artykułu: 19.12.2018

TOMASZ HODANA

Uniwersytet Jagielloński, Polska

\title{
Śmierć grzesznika w prawosławnej literaturze polemicznej epoki unii brzeskiej
}

W dawnej kulturze Słowian wschodnich, podobnie jak w całym chrześcijańskim średniowieczu, śmierć była postrzegana jako kluczowy moment ludzkiego życia. Wierzono, że w ostatniej godzinie może rozstrzygnąć się kwestia zbawienia lub potępienia, a sposób przejścia na tamten świat ujawnia prawdę o ostatecznym losie człowieka. Śmierć stanowiła również stały motyw ówczesnego piśmiennictwa, szczególnie hagiografii, przy czym oprócz rozlicznych epizodów „dobrej śmierci” literatura zachowała wiele budzących grozę scen umierania grzeszników. Ich nagły i nędzny koniec był zazwyczaj — zarówno w wymiarze ideowym, jak i formalnym — antytezą dostojnej i błogosławionej śmierci świętych ${ }^{1}$.

Motyw „złej śmierci” spotykamy często w prawosławnej literaturze polemicznej, która rozwijała się na Białorusi i Ukrainie pod koniec XVI i w pierwszej

${ }^{1} \mathrm{Na}$ temat typowych elementów biografii świętego i grzesznika, w tym „dobrej” i „złej” śmierci, zob. m.in. М. Г. Кротов, Послание ияаря Алексея Михайловича о смерти патриарха Иосифа (этюд из исторической психологии), [w:] Герменевтика древнерусской литературь XVI- нач. XVIII вв., t. 2, Москва 1989, s. 149-179; Л. А. Черная, История культуры Древней Руси, Москва 2007, s. 128-132; еаdem, Антропологический код древнерусской культуры, Москва 2008, http:/fictionbook.ru/static/trials/00/27/46/00274672.a4.pdf [dostęp: 13.09.2017]; Г. Г. Донской, Переход в „иной мир” в духовной культуре средневековой Руси (XIV-XVI вв.) [диссертация на соискание ученой степени кандидата исторических наук], Москва 2012. O ścisłym związku żywotu i ,antyżywotu” pisze również Władimir Wasiljew, który oba schematy fabularne traktuje jako wcielenie archetypicznych „opowieści” o Chrystusie i Antychryście - В. К. Васильев, Сюжетная типология жанра жития в русской литературе XI-XVI веков [автореферат диссертации на соискание ученой степени кандидата филологических наук], Томск 2008; idem, Сюжетная типология русской литературы XI-XX веков (Архетипы русской культуpы). От Средневековья к Новому времени, Красноярск 2009; idem, Сюжет позднего русского Средневековья (в сочинениях князя А. Курбского и протопопа Аввакума), „Вестник Новосибирского государственного университета”, серия „История, Филология” 9, 2010, z. 2: Филология, s. 134-140.

Slavica Wratislaviensia 168, 2019

(C) for this edition by CNS 
połowie XVII stulecia. Jak wiadomo, była ona reakcją na zawarcie unii brzeskiej (1596) oraz odpowiedzią na propagandę wyznaniową Kościoła katolickiego i nowo powstałej Cerkwi unickiej. Z uwagi na specyficzną genezę i funkcję tekstów polemicznych, w roli ginących marnie grzeszników występują tam odstępcy od wiary greckiej - przede wszystkim biskupi, którzy uznali zwierzchność Rzy$\mathrm{mu}$ - konwertyci oraz innowiercy, w tym szczególnie wrogowie i prześladowcy Cerkwi, burzyciele tradycji religijnej, świętokradcy i bluźniercy.

W porównaniu z literaturą staroruską - średniowieczną parenetyką, latopisarstwem czy hagiografią - opisy śmierci grzeszników, pojawiające się w polemice międzywyznaniowej, mają wymiar zdecydowanie mniej uniwersalny. W strukturze poszczególnych utworów odgrywają na ogół rolę ostrzegawczych przykładów, po które sięga się przy okazji poruszania najróżniejszych tematów bieżących. Występują między innymi w kontekście sporu o kanoniczność synodu brzeskiego, kontrowersji związanych z przejmowaniem świątyń i majątków, dysput wokół reformy kalendarza czy wreszcie apologii i obrony prawosławnych miejsc kultu, ikon i relikwii.

Pomimo specyficznej funkcji i aktualnego wydźwięku literackie reprezentacje „złej śmierci” realizowane są według utrwalonego w tradycji schematu. Odstępcy od wiary giną w sposób nagły, bez możliwości zamknięcia spraw doczesnych oraz duchowego przygotowania się na sąd Boży. Umierają w stanie bądź grzesznej pychy i zatwardziałości serca, bądź zgubnej rozpaczy. W chwili konania pozostają najczęściej samotni lub otoczeni przez wrogów, a dodatkowe, budzące wstręt lub grozę, okoliczności ich odejścia podkreślają grzeszne skłonności oraz występki popełnione za życia. W wielu wypadkach mamy do czynienia ze śmiercią nienaturalną: zabójstwem albo zgonem, który prezentowany jest jako efekt działania sił nadprzyrodzonych. Śmierć bywa wówczas gwałtowna i może nastąpić - ku przestrodze — na oczach wielu świadków. Popularnymi motywami są również pośmiertne znaki potępienia, okaleczenie lub zbezczeszczenie ciała, a wreszcie brak godnego chrześcijańskiego pochówku.

Dla pisarzy tworzących w epoce unii brzeskiej pierwowzorem „złej śmierci” pozostaje samobójstwo Judasza, haniebne zgony dawnych herezjarchów z Ariuszem na czele oraz nędzny kres księcia Światopełka — zabójcy świętych Borysa i Gleba. Dodatkowo chętnie przypomina się marny koniec tych, którzy — już po rozłamie chrześcijaństwa - próbowali poddać Kościół wschodni pod władzę papieża. Najczęściej przywoływanym przykładem są tragiczne zgony sygnatariuszy unii florenckiej (1439); ponieważ w piśmiennictwie katolickim stanowiła ona przykład autentycznego zjednoczenia Kościołów, prawosławni chętnie przypominali jej dramatyczny finał.

Najbardziej rozległą polemiczną relację na temat soboru florenckiego można odnaleźć w broszurze niejakiego Kliryka Ostrogskiego². Opisuje on między

${ }^{2}$ Исторіа о Листрикійском, то есть, о разбойническомъ, Ферарскомъ або Флоренскомъ синодъ, вкоротиґ правдиве списаная, [w:] Памятники полемической литературь 
innymi śmierć greckich dostojników, którzy przyczynili się do zawarcia unii: patriarchy Konstantynopola Józefa II, cesarza Jana VIII Paleologa i metropolity kijowskiego Izydora. Patriarcha został podstępnie zamordowany przez łacińskich mnichów, gdy chciał się wycofać z porozumienia (do którego skłoniono go wcześniej prezentami). Z kolei cesarz, którego skuszono „wielkimi podarkami” i ,jeszcze większymi obietnicami”, zmarł nagle w drodze powrotnej do swojej stolicy, dręczony przed śmiercią wyrzutami sumienia. „Poznał swój występek czytamy - którym Boga obraził, sprzedawszy swoje sumienie za złoto, i tamże w rozpacz wpadłszy, zdechł nagle"3. Trzeci zwolennik porozumienia z Rzymem, metropolia Izydor, gdy doświadczył oporu ruskich wiernych i na własne oczy ujrzał upadek Konstantynopola, również „żałował swojego uczynku, a prawie przez Boga i przez ludzi opuszczonym będąc, a nawet przez swoje własne owieczki począł rozpaczać"4. Widząc to, jego sługa i kaznodzieja, archidiakon Benedykt, „chwalca stolicy rzymskiej”, podał mu w posiłku truciznę 5 .

W opowieści Kliryka z Ostroga można odnaleźć kilka typowych elementów „złej śmierci”: po pierwsze — spóźniony żal, wyrzuty sumienia i zgubną dla duszy rozpacz, po drugie - śmierć w osamotnieniu i na obcej ziemi (co jest szczególnie wymowne w wypadku cesarza), po trzecie wreszcie - śmierć nienaturalną: uduszenie patriarchy i otrucie metropolity. Wszystko to ma podkreślać bezbożność unii florenckiej i wskazywać, że podobny los czeka biskupów, którzy podpisali akt unii brzeskiej.

Dla porządku przypomnijmy, że na synodzie w Brześciu Litewskim za zjednoczeniem z Kościołem zachodnim opowiedziało się sześciu hierarchów ówczesnej metropolii kijowskiej ${ }^{6}$. U schyłku pierwszej dekady XVII wieku, czyli nieco ponad dziesięć lat później, przy życiu pozostał już tylko jeden. Jak nietrudno się domyślić, fakt ten stał się częstym motywem prawosławnych pism polemicznych i był interpretowany jako kara Boża za zdradę wiary.

Wzmianki o tajemniczych zgonach pierwszych unickich biskupów pojawiają się w wielu tekstach z tego okresu, między innymi w anonimowej Przestrodze

въ Западной Руси, ks. 3, „Русская Историческая Библіотека”, t. 19, Петербургъ 1903, kol. 433-476. Obszerne fragmenty dzieła w przekładzie Jana Stradomskiego zostały zamieszczone w A. Naumow, Domus divisa. Studia nad literatura ruska w I. Rzeczypospolitej, „Biblioteka Tradycji Literackich” t. 18, Kraków 2002, s. 259-283 (cytuję za tym właśnie wydaniem).

3 A. Naumow, Domus divisa..., s. 277; w oryginale: „Позналь свой выступокъ, которымъ Бога образилъ, продавши за злото сумненье свое. Тамъ же впадши въ роспачъ, нагле здохъ” - Исторіа о Листрикійском..., kol. 467.

${ }^{4}$ A. Naumow, Domus divisa..., s. 278-279; w oryginale: „[...] жаловаль учинку своего, а праве отъ Бога и отъ людей, а иле своихъ овечокъ власныхъ - опущонъ будучи, почалъ розпачати" - Исторіа о Листрикійском..., kol. 469.

${ }^{5}$ Por. ibidem.

${ }^{6}$ Do unii przystąpili: metropolita Michał Rahoza, biskup łucki Cyryl Terlecki, biskup włodzimierski Hipacy Pociej, arcybiskup połocki Herman Zahorski, biskup chełmski Dionizy Zbirujski oraz biskup piński Jonasz Hohol. Przy prawosławiu pozostali: biskup lwowski Gedeon Bałaban oraz biskup przemyski Michał Kopysteński. 
(1605-1606) $)^{7}$, Threnosie (1610) Melecjusza Smotryckiego 8 i Palinodii (1621) Zachariasza Kopysteńskiego ${ }^{9}$. Z wymienionych dzieł najpełniej rzecz całą prezentuje Threnos. Mamy tam opis zgonu pogrążonego w rozpaczy metropolity Michała Rahozy, który ,jeszcze żywym będąc, jako umarły chodził i śmierć nagłą, desperackie głosy wypuszczając, podjął"10. Jest też wzmianka o śmierci arcybiskupa połockiego Hermana Zahorskiego, który umarł przy ołtarzu w trakcie napadu epilepsji, czyli — zdaniem Smotryckiego — został zabity przez złego ducha. Są wreszcie zgony niegodne bądź w stanie grzechu ciężkiego. I tak, władyka piński Jonasz Hohol skręcił kark, „ożarszy się gorzałki”, władyka chełmski Dionizy Bałaban umarł obłożony klątwą za niekanoniczny związek z kobietą, a biskup łucki Cyryl Terlecki „za drugimi się pośpieszył”, pogrążony w rozpuście i z nieodpokutowanym morderstwem na sumieniu ${ }^{11}$. Cały fragment ma być mementum dla ostatniego żyjącego „ojca unii brzeskiej” — biskupa włodzimierskiego Hipacego Pocieja, który w momencie powstawania Threnosu piastował urząd metropolity. Autor upomina go następującymi słowy: „Wspomnij, synu, co się nad bracią Twoją mało przed tym stało, którzy na tejże z Tobą drodze byli" ${ }^{\prime 2}$, na koniec zaś ostrzega: ,już z tego poszóstnego tej waszej unii cugu, ty tylko sam zostałeś, któremu P[an] Bóg Wszechmogący, snadź oczekiwając opamiętania i nawrócenia, jeszcze dotąd folgować i lat żywota przedłużać raczy"13.

Pozostałe dzieła zasadniczo powtarzają bądź uzupełniają wskazane wątki. Jedyną wartą odnotowania modyfikacją jest opis śmierci Michała Rahozy pojawiający się w Palinodii. Jej autor dodaje scenę, jaka miała się rozegrać przy łożu śmierci hierarchy: „I do tego przyszło, że [...] odwoływał swoją apostazję, i z całej duszy o prawosławnego duchownego prosił, którego mu protektorzy [jego], łacinnicy, wzbronili i [doń] nie dopuścili’"14. Pierwszy unicki metropolita umiera zatem nie tylko w rozterkach sumienia, lecz także pozbawiony ostatnich sakramentów.

${ }^{7}$ Пересторога зело потребная на потомные часы православным христіаном..., [w:] М. Возняк, Письменнищька діяльність Івана Борещького на Волині і у Львові, Львів 1954, s. 25-63.

${ }^{8}$ Threnos to jest Lament jedynej ś. powszechnej apostolskiej wschodniej Cerkwie, z objaśnieniem dogmat wiary. Pierwej z greckiego na słowieński, a teraz z słowieńskiego na polski przełożony. Przez Theophila Orthologa, tejże świętej wschodniej Cerkwie syna, [w:] Collected Works of Meletij Smotryc'kyj, wstęp D. A. Frick, „Harvard Library of Early Ukrainian Literature. Texts", t. 1, Cambridge MA 1987, s. 1-235.

${ }^{9}$ Палінодія или Книга Обороны Кафолической Святой Апостолской Всходней Церкви и Святыхъ Патріарховъ, и о Грекохъ, и о Россохъ христіанехъ..., [w:] Памятники..., ks. 1, „Русская Историческая Библіотека”, t. 4, Петербургъ 1878, kol. 313-1200.

${ }^{10}$ Threnos..., s. 92.

11 Por. ibidem, s. 92-93.

12 Ibidem, s. 92.

13 Ibidem, s. 93.

14 „И пришло до того, же при смерти отволываль свою апостасію, и о православного духовника зъ души жадалъ. Еножъ предстатели Латинникове зборонили и не допустили" — Палінодія..., kol. 1045. Jeśli nie podano inaczej, przeł. T. Н. 
Jeszcze bardziej sugestywna jest anonimowa opowieść o śmierci biskupa łuckiego Cyryla Terleckiego, która zachowała się w jednym z rękopisów ${ }^{15}$. Wypada $\mathrm{w}$ tym miejscu przypomnieć, że Terlecki, jeden z głównych — obok Pocieja - inicjatorów unii brzeskiej, był na przełomie XVI i XVII wieku popularnym „,czarnym charakterem” literatury polemicznej. W tekstach prawosławnych autorów jawił się — nie bez podstaw ${ }^{16}$ - jako rozpustnik, morderca i grabieżca, fałszerz pieniędzy, oszust i uzurpator, „wilk w owczej skórze” oraz — by posłużyć się charakterystycznym określeniem, przywołanym w Apokrisis Marcina

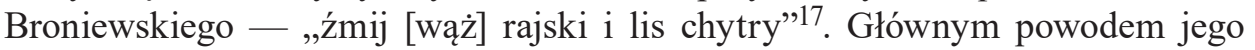
dążenia do unii miała być niepohamowana chciwość; chętnie też wytykano mu rozwiązłość, fałsz i obłudę. Autor wspominanej Przestrogi szczegółowo opisuje, jak w trakcie wizyty patriarchy Konstantynopola Jeremiasza II w Rzeczypospolitej Cyryl podstępnie przejmował jego pisma, a jednocześnie pochlebstwem wyłudził tytuł egzarchy, czyli patriarszego namiestnika. W tym samym czasie miał potajemnie namawiać pozostałych władyków, by odrzucili zwierzchnictwo patriarchy, obiecując, że poddanie się władzy papieża przyniesie im rozliczne korzyści ${ }^{18}$.

Dopełnieniem nakreślonego wizerunku jest wspomniana relacja o śmierci; jak można w niej przeczytać:

Cyryl Terlecki, władyka łucki, na Wołyniu śmiercią złą i szkaradną umarł. Udusił go szatan niespodzianie, w piwniczce, nad beczkami pełnymi pieniędzy. I nie mogli go odnaleźć, bo go diabeł, udusiwszy, w pustą beczkę włożył. A gdy go na drugi dzień znaleźli, pan Iwan Welatycki, pisarz piński, przyśrubował go do karety i po wsiach obwoził, od poddanych jego czynsz zbierając, jak gdyby żył [jeszcze]. Potem zaś wrzucił go w błoto. I tam mu wrony oczy wydziobały. Dowiedziawszy się o tym, córka jego [Terleckiego], Welatycka, bo mu Welatycki zięciem był, kazała chłopom męża wyciągnąć ciało z błota i zakopać. I tak bez pogrzebu zginął. A to dlatego, że stał się uczestnikiem herezji manichejskiej i ariańskiej

15 Tekst, opatrzony redakcyjnym tytułem Полемічний опис смерті уніатських єпископів К. Терлецького та Г. Загорського, został opublikowany w zbiorze dokumentów zatytułowanym Боротьба Південно-Західної Русі і України проти експансії Ватікану та унії (X-початок XVII cm.). Збірник документів і матеріалів, red. Є. А. Гринів et al., Київ 1988, nr 137, s. 192. Zamieszczony tam krótki opis śmierci arcybiskupa połockiego Hermana Zahorskiego powtarza motyw zawarty w Threnosie.

16 Por. m.in. О. Левицкий, Южно-русские архиереи в XVI-XVII в., „Киевская Старина" 1, 1882, s. 49-100; Л. Тимошенко, Спископ Кирило Терлечький: родовід і початок духовної кар'єри, „Дрогобицький Краєзнавчий Збірник” 9, 2005, s. 202-213; idem, 3аповiтu, смерть і поховання єпископа Кирила Терлецького, „Дрогобицький Краєзнавчий Збірник” 11-12, 2008, s. 467-483; П. Кралюк, Спископ переломних часів. Непочінований Кирило Терлецький, „День” 3.08.2007, nr 128, https://day.kyiv.ua/uk/article/ukrayina-incognita/iepiskopperelomnih-chasiv-0 [dostęp: 13.09.2017]; „День” 10.08.2007, nr 133, https://day.kyiv.ua/uk/ article/ukrayina-incognita/iepiskop-perelomnih-chasiv [dostęp: 13.09.2017].

17 Słów tych jeszcze przed unią brzeską miał użyć względem Terleckiego metropolita Rahoza w liście do księcia Konstantego Wasyla Ostrogskiego; por. Apokrisis abo Odpowiedź na książki o synodzie brzeskim..., [w:] Памятники..., ks. 2, „Русская Историческая Библіотека”, t. 7, Петербургъ 1882, kol. 1057.

18 Por. Пересторога..., s. 29-32. 
i zdrajcą Cerkwi wschodniej: dwa początki Duchowi Świętemu przypisywał i w posłuszeństwo papieżowi się odda1 ${ }^{19}$.

Przytoczony opis — choć sam w sobie niezwykle wymowny — wymaga kilku słów komentarza. Śmierć w trakcie liczenia pieniędzy jest oczywistym nawiązaniem do przypowieści o głupim bogaczu (por. Łk 12,13-21), a zarazem aluzją do złodziejskiej natury Judasza, z którym Terlecki był wielokrotnie zestawiany. Chciwość biskupa zostaje dodatkowo podkreślona w scenie pośmiertnego obwożenia ciała i zbierania opłat (dodajmy, że motywy ukrycia, szukania i odnalezienia, a potem publicznego eksponowania doczesnych szczątków to przewrotne odwołanie do hagiografii). Warte uwagi jest również to, że w tę de facto profanację zwłok i makabryczne oszustwo zaangażowani są bezpośrednio zięć i córka zmarłego. To kolejny wątek, który może towarzyszyć „,złej śmierci” nieuporządkowane relacje z bliskimi, zwłaszcza brak przedśmiertnego pojednania. W cytowanej opowieści nie jest to wprawdzie powiedziane wprost, a inne teksty polemiczne tematu nie poruszają, jednak z zachowanych aktów sądowych oraz testamentów łuckiego władyki wiadomo, że w ostatnich latach życia był mocno skonfliktowany z częścią rodziny ${ }^{20}$. Opis szkaradnego zgonu uzupełnia obraz ciała porzuconego na pastwę zwierząt oraz podkreślenie, że nie doczekało się ono godnego pochówku.

Podsumowując, można stwierdzić, że „zła śmierć” Cyryla Terleckiego jest zasłużoną odpłatą za zdradę prawosławia, a jednocześnie napiętnowaniem chciwości, czyli grzechu, który go do tej zdrady doprowadził. Przypomina także o przewrotnej naturze wiarołomnego biskupa i pokazuje, że tak za życia, jak i po śmierci znajdował się pod władzą złego ducha.

Inną kategorią grzeszników spektakularnie uśmiercanych w literaturze polemicznej są prześladowcy Cerkwi - najczęściej kolejni uniccy hierarchowie, którzy grabią lub zajmują prawosławne świątynie i majątki, a także wspierający

19 „Кирил Терлецький, владика луцький, на Волині злою а шкарадною смертю вмер. Вдавил єго шатан в склепі над бочками грошей нагло. I не могли єго найти, ано єго диявол, вдавивши, в порожню бочку вложил. А кгди єго дня другого найшли, пан Іван Велятицький, писар пінський, пришрубовал єго в кареті і возил по селах в подданих чинш вибираючи на него, якби жив. А потом вкинул єго в болото. І там му ворони очі вибрали. Довідавшися дочка єго Велятицькая, бо му Велятицький бил зять, казала потом мужа хлопам вийняти з болота і закопати. I так без погреба згиб. А то для того же стал учасником єреси маніхеської і часто аріяньськоє і зрадницею церкви восточної. Два початки духу святому чинил, послушенство папежу отдал" - Боротьба Південно-Західної Русі і України..., s. 192.

${ }^{20}$ W 1599 roku Terlecki oskarżył swojego zięcia, wspomnianego tu Iwana Welatyckiego, oraz córkę Annę o napaść zbrojną i chęć grabieży majątku, a także wytoczył im proces sądowy, rok wcześniej zaś zmienił spisany uprzednio testament, pozbawiając ich prawa do spadku. Wprawdzie kilka lat później postanowił wybaczyć córce oraz zięciowi i w kolejnym testamencie, sporządzonym tuż przed śmiercią, zapisał im większą część swoich dóbr, o tym jednak autor przywoływanej opowieści mógł już nie wiedzieć lub fakt ten świadomie przemilczał; por. Л. Тимошенко, Заповіти, смерть і поховання..., s. 468-473. 
ich w tym bezbożnym dziele świeccy urzędnicy oraz katolicka bądź unicka czeladź. Przykładów jest wiele. Jeden z najbardziej barwnych to opowieść o śmierci biskupa chełmskiego Atanazego Pakosty, spisana na początku lat trzydziestych XVII wieku przez Piotra Mohyłę ${ }^{21}$. Unicki władyka, którego nazwisko przybiera w tej historii charakterystyczny — nomen est omen — wariant „Pakość” („Пакость” $)^{22}$, prześladuje prawosławnych duchownych i wiernych diecezji chełmskiej. Pewnego dnia, gdy wdziera się przemocą do cerkwi Świętej Paraskiewy w Krasnymstawie, niewidzialna siła trzykrotnie odrzuca go od ołtarza, nieomal zabijając na miejscu. Nie zważając na to ostrzeżenie, Pakosta nakazuje zamknięcie świątyni i nadal dręczy prawosławnych, za co wkrótce zostaje ukarany ciężką chorobą. Chcąc odzyskać zdrowie, za namową czarowników poleca zabić swojego kucharza i skrapia się jego krwią, potem zaś ,serce jego, bijące jeszcze, wyrwać każe, i upiekłszy, sam jak zwierz dziki zjada"23. Te makabryczne zabiegi nie odnoszą, rzecz jasna, żadnego skutku i po kilku dniach bezbożny biskup umiera:

[...] po życiu jego śmierć straszna i niemiłościwa nastąpiła: jak bowiem tylko duszę nieczystą i niemiłościwą oddał, strasznie i niemiłościwie biesy głowę jego występną wraz z szyją od ciała nieczystego i Bogu ohydnego gwałtem niewidzialnie oderwały, która w przytomności wszystkich od ciała się oddzieliła i z łoża na ziemię upadła, na zadziwienie wszystkich i na świadectwo nieprawego ich [unitów] odstępstwa. Zła jest bowiem śmierć grzeszników ${ }^{24}$.

W tej na poły fantastycznej relacji po raz kolejny odnajdujemy liczne typowe elementy „złej śmierci”: lekceważenie nadprzyrodzonych znaków, które świadczy o zatwardziałości serca; budzące grozę okoliczności umierania, w tym cha-

${ }^{21}$ Рог. Сказанія Петра Могиль о чудесныхъ и замечательных явленіяхъ въ иеркви православной..., [w:] Архивъ Юго-Западной Россіи, сz. 1, t. 7, Кіев 1887, s. 114-116. Swoją energiczną działalnością, dobrze opisaną w źródłach historycznych, Pakosta mocno dał się we znaki prawosławnym; por. m.in. skargę ruskich mieszczan do sądu grodzkiego w Busku i list bractwa cerkiewnego z Krasnegostawu do bractwa lwowskiego opublikowane w tomie Боротьба Південно-Західної Русі і Украӥни..., s. 214-216; zob. także A. Gil, Chetmska diecezja unicka 1596-1810. Dzieje i organizacja, „Studia i Materiały do Dziejów Chrześcijaństwa Wschodniego w Rzeczypospolitej", t. 1, Lublin 2005, s. 61-62, 66-67.

22 „По имени его бысть и житіе его” — podkreśla autor relacji (Сказанія Петра Могилы..., s. 114). Słowo „пакость” ma kilka znaczeń, a wszystkie negatywne: 1) 'zło', 'szkoda', 'uszczerbek'; 2) 'pohańbienie', 'zbezczeszczenie'; 3) 'niepokój'; 4) 'przeszkoda'; 5) 'utrapienie', 'bieda', 'nieszczęście'; 6) 'nieczystość', 'obrzydliwość', 'ohyda'; zob. m.in. Словарь русского языка XI-XVII вв., t. 14: Отрава - Персоня, Москва 1988, s. 130.

23 ,[...] сердце его, еще движущееся сторгнути [повели], и испекши е, самъ аки звърь изъяде" - Сказанія Петра Могильк..., s. 115.

24, ,...] по житію его и кончина его люта и немилостива бысть: егда бо испроверзаше скверную и немилостивую душу свою, страшно и немилостивно бъсы хулную его главу съ выею отъ нечистаго и богомерзкаго тъла его насиліемъ невидимо исторгоша, якъ же предъ всьми предстоящими на землю отъ тьла и отъ одра испасти, во удивленіе всьмъ и въ обличеніе беззаконнаго ихъ отступства. Смерть бо грьшникомъ люта” —ibidem, s. 115-116. 
rakterystyczne „zezwierzęcenie” grzesznika ${ }^{25}$; a wreszcie — pośmiertne znaki potępienia dokonujące się na oczach wielu świadków.

W tym samym zbiorze pojawia się jeszcze historia przerażającej śmierci starosty przemyskiego, który pomagał unickiemu biskupowi Atanazemu Krupieckiemu odebrać prawosławnym sobór katedralny Świętego Jana Chrzciciela, oraz wzmianka o nagłym zgonie ślusarza, który na rozkaz urzędnika sforsował drzwi do świątyni. Co charakterystyczne, starostę miał przed śmiercią „dręczyć okrutnie" sam święty Jan, czyli patron zagarniętej katedry ${ }^{26}$.

Pozostałe kategorie karanych ,złą śmiercią” grzeszników, o których nie sposób tu szerzej opowiedzieć, to między innymi: katolicy demonstracyjnie lekceważący kalendarz juliański bądź zmuszający prawosławnych do świętowania zgodnie z nowym stylem, a także świętokradcy i bluźniercy — głównie protestanci - szydzący z obrzędów cerkiewnych i podnoszący rękę na rozmaite świętości, przede wszystkim relikwie ${ }^{27}$. Odrębną grupę stanowią młodzi przedstawiciele prawosławnych rodów magnackich, którzy — niepomni na przestrogi oraz rozmaite cudowne znaki - porzucają wiarę przodków i umierają nagle, w kwiecie wieku, nie pozostawiwszy po sobie potomstwa ${ }^{28}$.

We wszystkich wskazanych przypadkach motyw „złej śmierci” pełni funkcję poręcznego argumentu w dyspucie. Niezależnie od tego, czy pojawia się w formie wzmianki, czy też bardziej rozbudowanego epizodu, ma służyć przede wszystkim jako ostateczne potwierdzenie racji ortodoksyjnego autora. Staje się dowodem świętości jego rodzimej tradycji, a równocześnie znakiem potępienia kultur i wspólnot innowierczych. Dowodem, rzecz jasna, nie dla unitów, katolików czy protestantów, ale dla pobożnego prawosławnego czytelnika. Ta jednostronność i ekskluzywizm są nader charakterystyczne dla całej polemiki okołounijnej i nie

25 Por. m.in. О. А. Туфанова, „Кровоядный лвичищ”” Гришка Отрепьев, „Вестник Славянских Культур” 11, [Москва] 2009, nr 1, s. 89-96; А. С. Демин, Изображение „зверскости” злодеев в древнерусской литературе, „Вестник Славянских Культур” 29, [Москва] 2013, nr 3, s. $68-81$.

${ }^{26}$ Рог. Сказанія Петра Могиль..., s. 61.

${ }^{27}$ Por. m.in. wzmiankę o śmierci autora reformy kalendarzowej, papieża Grzegorza XIII, z broszury Herasyma Smotryckiego Kalendarz rzymski nоwy (Каленъдаръ Римский новый, [w:] Архивъ Юго-Западной Россіи, cz. 1, t. 7, Кіев 1887, s. 252) oraz barwne historie z przywoływanych Opowieści Mohyły (Сказанія Петра Могиль..., s. 53-54, 104-105, 123-124) і słynnej pracy Atanazego Kalnofojskiego (Teraturgema lubo Cuda, które byly tak w samym świętocudotwornym monastyru pieczarskim kijowskim jako w obudwu świętych pieczarach..., [Kijów 1638], [w:] Seventeenth-Century Writings on the Kievan Caves Monastery, „Harvard Library of Early Ukrainian Literature. Texsts", t. 4, Cambridge MA 1987, s. 195-196, 202-203, 258-259.

28 Por. m.in. słowa Iwana Wiszeńskiego o upadku domu książąt Słuckich oraz śmierci ks. Konstantego Konstantynowicza Ostrogskiego (И. Вишенский, Сочинения, oprac. i koment. И. П. Еремин, Москва-Ленинград 1955, s. 33-34) oraz obszerną opowieść Mohyły o śmierci dwóch innych książąt Ostrogskich — Konstantego i Janusza, synów ks. Aleksandra Konstantynowicza Ostrogskiego i Anny Kostczanki, którzy byli ostatnimi męskimi przedstawicielami słynnego rodu (Сказанія Петра Могиль..., s. 93-98; zob. także Н. Яковенко, Паралельний світ. Дослідження з історії уявлень та ідей в Украӥні XVI-XVII cm., Київ 2002, s. 22). 
ograniczają się bynajmniej do przedstawicieli Kościoła wschodniego. Jak to celnie ujął Aleksander Brückner, wszyscy pisarze religijni tamtej epoki, ,wstępując w szranki, nie walczą nigdy o zdobycie prawdy; każdy z nich jest już w zupełnym jej posiadaniu" 29 .

\section{Bibliografia}

Broniewski M., Apokrisis abo Odpowiedź na ksiażki o synodzie brzeskim..., [w:] Pamyatniki polemicheskoi literatury v” Zapadnoi Rusi, ks. 2 „Russkaya Istoricheskaya Biblioteka”, t. 7 , Peterburg 1882.

Brückner A., Spory o unię w dawnej literaturze, „Kwartalnik Historyczny” 10, 1896.

Chernaya L. A., Antropologicheskii kod drevnerusskoi kul 'tury, Moskva 2008, http://fictionbook.ru/ static/trials/00/27/46/00274672.a4.pdf.

Chernaya L. A., Istoriya kul'tury Drevnei Rusi, Moskva 2007.

Demin A. S., Izobrazhenie „zverskosti” zlodeev v drevnerusskoi literature, „Vestnik Slavyanskikh Kul'tur" 29, [Moskva] 2013, nr 3.

Donskoi G. G., Perekhod v ,,inoi mir" v dukhovnoi kul'ture srednevekovoi Rusi (XIV-XVI vv.) [dissertatsiya na soiskanie uchenoi stepeni kandidata istoricheskikh nauk], Moskva 2012.

Gil A., Chetmska diecezja unicka 1596-1810. Dzieje i organizacja, „Studia i Materiały do Dziejów Chrześcijaństwa Wschodniego w Rzeczypospolitej”, t. 1, Lublin 2005.

Jakovenko N., Paralel'nyj svit. Doslidzhennja z istorii' ujavlen' ta idej v Ukrai'ni XVI-XVII st., Kyi’v 2002.

Kalnofojski A., Teraturgema lubo Cuda, które były tak w samym świętocudotwornym monastyru pieczarskim kijowskim jako w obudwu świętych pieczarach..., [Kijów 1638], [w:] Seventeenth-Century Writtings on the Kievan Caves Monastery, „Harvard Library of Early Ukrainian Literature. Texsts", t. 4, Cambridge MA 1987.

Kliryk Ostrogski, Istoria o Listrikiiskom, to est', o razboinicheskom ", Ferarskom " abo Florenskom" sinodé, vkorottsě pravdive spisanaya, [w:] Pamyatniki polemicheskoi literatury v" Zapadnoi Rusi, ks. 3, „Russkaya Istoricheskaya Biblioteka”, t. 19, Peterburg” 1903.

Kopysteński Z., Palinodiya ili Kniga Oborony Kafolicheskoi Svyatoi Apostolskoi Vskhodnei Tserkvi i Svyatykh" Patriarkhov", i o Grekokh", i o Rossokh" khristianekh"..., [w:] Pamyatniki polemicheskoi literatury v” Zapadnoi Rusi, ks. 1, „Russkaya Istoricheskaya Biblioteka”, t. 4, Peterburg" 1878.

Kraljuk P., Jepyskop perelomnyh chasiv. Nepocinovanyj Kyrylo Terlec'kyj, „Den”" 3.08.2007, nr 128, https:/day.kyiv.ua/uk/article/ukrayina-incognita/iepiskop-perelomnih-chasiv-0; „Den”” 10.08.2007, nr 133, https://day.kyiv.ua/uk/article/ukrayina-incognita/iepiskop-perelomnihchasiv.

Krotov M. G., Poslanie tsarya Alekseya Mikhailovicha o smerti patriarkha Iosifa (etyud iz istoricheskoi psikhologii), [w:] Germenevtika drevnerusskoi literatury XVI-nach. XVIII vv., t. 2, Moskva 1989.

Levitskii O., Yuzhno-russkie arkhierei v XVI-XVII v., „Kievskaya Starina” 1, 1882.

Naumow A., Domus divisa. Studia nad literatura ruska w I. Rzeczypospolitej, „Biblioteka Tradycji Literackich", t. 18, Kraków 2002.

Perestoroga zelo potrebnaja na potomnyje chasy pravoslavnym khrystianom..., [w:] M. Voznjak, Pys 'mennyc'ka dijal 'nist' Ivana Borec'kogo na Volyni i u L'vovi, L'viv 1954.

Polemichnyj opys smerti uniats'kyh jepyskopiv K. Terlec'kogo ta G. Zagors'kogo, [w:] Borot'ba Pivdenno-Zahidnoi' Rusi i Ukrai'ny proty ekspansii' Vatikanu ta unii' (X-pochatok XVII st.). Zbirnyk dokumentiv i materialiv, red. J. A. Gryniv et al., Kyi'v 1988.

${ }^{29}$ A. Brückner, Spory o unię w dawnej literaturze, „Kwartalnik Historyczny” 10, 1896, s. 579.

Slavica Wratislaviensia 168, 2019

(C) for this edition by CNS 
Skazanija Petra Mogyly o chudesnyh" y zamechatel'nyh javlenijah" v" cerkvy pravoslavnoj..., [w:] Arhyv" Jugo-Zapadnoj Rossiy, cz. 1, t. 7, Kiev 1887.

Smotrycki H., Kalen"dar" Rimskii novyi, [w:] Arkhiv" Yugo-Zapadnoi Rossii, cz. 1, t. 7, Kiev 1887. Smotrycki M., Threnos to jest Lament jedynej ś. powszechnej apostolskiej wschodniej Cerkwie, $z$ objaśnieniem dogmat wiary. Pierwej z greckiego na słowieński, a teraz z słowieńskiego na polski przełożony. Przez Theophila Orthologa, tejże świętej wschodniej Cerkwie syna, [w:] Collected Works of Meletij Smotryc'kyj, wstęp D. A. Frick, „Harvard Library of Early Ukrainian Literature. Texts", t. 1, Cambridge MA 1987.

Tufanova O. A., , Krovoyadnyi lvichishch” Grishka Otrep'ev, „Vestnik Slavyanskikh Kul'tur” 11, [Moskva] 2009, $\mathrm{nr} 1$.

Tymoshenko L., Jepyskop Kyrylo Terlec 'kyj: rodovid i pochatok duhovnoi'kar 'jery, „Drogobyc'kyj Krajeznavchyj Zbirnyk" 9, 2005.

Tymoshenko L., Zapovity, smert' i pohovannja jepyskopa Kyryla Terlec'kogo, „Drogobyc'kyj Krajeznavchyj Zbirnyk" 11-12, 2008.

Vasil'ev V. K., Syuzhet pozdnego russkogo Srednevekov'ya (v sochineniyakh knyazya A. Kurbskogo i protopopa Avvakuma), „Vestnik Novosibirskogo Gosudarstvennogo Universiteta”, seria „Istoriya, Filologiya” 9, 2010, z. 2. Filologiya.

Vasil'ev V. K., Syuzhetnaya tipologiya russkoi literatury XI-XX vekov (Arkhetipy russkoi kul'tury). Ot Srednevekov'ya k Novomu vremeni, Krasnoyarsk 2009.

Vishenskiy I., Sochineniya, oprac. i koment. I. P. Yeremin, Moskva-Leningrad 1955.

\section{The death of a sinner in Orthodox polemical literature of the era of the Union of Brest}

\section{Summary}

In the Orthodox polemics of the end of the 16th and the first half of the 17th century, sinners, dying of a "bad death", are most often apostates from the faith (bishops who joined the Union of Brest), converts, and religious dissenters, especially persecutors of the Orthodox Church, and those committing sacrilege and blasphemy. Descriptions of their miserable deaths are based on a traditional Old East Slavic schema, but they have a particular, less universal dimension. They generally act as cautionary examples, which are referred to when discussing current issues (the dispute over the legality of the Synod of Brest, the controversy over the acquisition of temples and properties, the debate over the calendrical reform, and the apologetics and defence of Orthodox sanctuaries, icons, and relics). In all cases, the death of a sinner (Uniate, Catholic or Protestant) becomes the final confirmation that the Orthodox author is right, as well as the evidence of the sanctity of his tradition, and the sign of condemnation of the religious dissenters.

Keywords: death of a sinner, bad death, Union of Brest, polemical literature, anti-hagiography 


\section{Смерть злодея в православной полемической литературе времен Брестской церковной унии}

\section{Резюме}

В православной полемической литературе конца XVI и первой половины XVII века в роли грешников, умирающих „злой смертью”, чаще всего выступают вероотступники (главным образом, епископы, признавшие Брестскую церковную унию 1596 года), люди, обращенные из православия, и инославные христиане, в первую очередь гонители Церкви, святотатцы и богохульники. Описания их жалкого конца опираются на традиционную древнерусскую модель, но в отличие от нее носят гораздо менее универсальный характер. Большей частью они играют роль назидательных примеров, к которым полемисты обращались в связи со злобой дня, такой как спор о каноничности брестского поместного собора, протесты против захвата православных храмов и имущества, разногласия насчет календарной реформы или же апология и защита православных святынь - церквей, икон и мощей. Во всех приведенных примерах смерть злодея (униата, католика или протестанта) является окончательным оправданием позиций благочестивого автора - доказательством богоугодности его собственной традиции и знаком осуждения любого инославия.

Ключевые слова: смерть грешника (злодея), „злая смерть”, Брестская церковная уния, полемическая литература, ,антижитие” 